\title{
MITOCHONDRIAL AND MICROSATELLITE DNA ANALYSES OF AUSTROPOTAMOBIUS PALLIPES POPULATIONS IN SOUTH TYROL (ITALY) AND TYROL (AUSTRIA)
}

\author{
S. BARIC (1) ${ }^{\star}$, A. HÖLLRIGL (1), L. FÜREDER (2), J. DALLA VIA (1)
}

(1) Research Centre for Agriculture and Forestry Laimburg. Laimburg 6, 39040 Auer/ Ora (BZ), Italy.

E-Mail: sanja.baric@provinz.bz.it

(2) Department of Zoology and Limnology. University of Innsbruck, Technikerstr. 25, 6020 Innsbruck, Austria.

* To whom correspondence should be addressed.

Reçu le 5 novembre 2004

Accepté le 17 février 2005

Received November 5, 2004

Accepted February 17, 2005

\begin{abstract}
Historical data show that the native white-clawed crayfish, Austropotamobius pallipes, was once widespread throughout South Tyrol (northern Italy), whereas recent studies identified only half a dozen remaining populations. In order to implement conservation strategies based on knowledge of genetic diversity, each of the six remaining populations in South Tyrol and one population in Tyrol (Austria) were investigated by (i) sequencing segments of two mitochondrial DNA genes, 16S rRNA and cytochrome $\mathrm{C}$ oxidase subunit I, and (ii) by analysing four microsatellite DNA loci. Extremely low degrees of genetic differentiation within and among the South Tyrolean populations of $A$. pallipes were found with mitochondrial DNA sequences. In contrast, microsatellite data displayed not only substantial genetic structure among populations, but also moderate genetic variability within four out of six populations in South Tyrol. The two remaining populations revealed a complete absence of genetic variability. Moreover, both of these populations as well as the population from Austria were fixed for single alleles at three of the four investigated microsatellite loci. Our data have important conservation implications and also show that mitochondrial DNA is not always a sufficient tool to study crayfish populations on a small geographical scale.
\end{abstract}

Key-words: white-clawed crayfish, genetic diversity, microsatellite DNA, mitochondrial DNA.

\section{ANALYSES DE L'ADN MITOCHONDRIAL ET DES MICROSATELLITES DES POPULATIONS D'AUSTROPOTAMOBIUS PALLIPES DANS DU TYROL DU SUD (ITALIE) ET DANS LE TYROL (AUTRICHE)}

\section{RÉSUMÉ}

Des données historiques montrent que l'écrevisse à pattes blanches, Austropotamobius pallipes, était fortement représentée dans tout le Tyrol du Sud (nord de I'Italie). Cependant, de récentes études portent à une demi-douzaine les populations 
encore existantes. Dans le cadre de la mise en place d'une stratégie de conservation, la diversité génétique de chacune de ces six populations ainsi que d'une population du Tyrol autrichien a été analysée (i) par séquençage de portions de deux gènes mitochondriaux, codant pour l'ARN $16 \mathrm{~S}$ et la cytochrome oxydase I et (ii) par analyse de quatre loci microsatellites. Une très faible différenciation génétique a été trouvée dans et entre les populations du Tyrol du Sud avec le marqueur mitochondrial. Au contraire, les données microsatellites montrent non seulement une substantielle structure génétique entre les populations, mais aussi une variabilité modérée dans quatre des six populations du Tyrol du Sud. De plus, deux de ces populations ainsi que celle d'Autriche montrent une fixation d'allèles pour trois des quatre loci microsatellite analysés. Nos données apportent d'importantes implications pour la conservation de la diversité génétique et montrent, également que l'ADN mitochondrial n'est pas toujours adapté pour étudier les populations d'écrevisses sur une petite échelle géographique.

Mots-clés : écrevisse à pattes blanches, diversité génétique, ADN microsatellite, ADN mitochondrial.

\section{INTRODUCTION}

Freshwater invertebrates and fishes are vulnerable to habitat loss and pollution, because of destruction and contamination of freshwater ecosystems (DYNESIUS and NILSSON, 1994). The loss of habitats and the subsequent fragmentation of populations is one of the most important factors in species extinction, as fragmentation usually reduces rates of gene flow among subpopulations and leads to a decrease in effective population size (NEY-NIFFLE and MANGEL, 2000). Small, isolated populations are particularly prone to loss of genetic variability through the action of genetic drift. This can have negative consequences on the long-term viability of a population, since genetic variability represents an important potential to cope with and adapt to changing environments.

In Europe, autochthonous freshwater crayfish belong to the most endangered aquatic species. Populations of the white-clawed crayfish, Austropotamobius pallipes, have declined by $25-50 \%$ over the last 25 years (BERNARDO, ILHEU and COSTA, 1997; GHERARDI, SOUTY-GROSSET and REYNOLDS et al., 2003; HOLDICH and ROGERS, 1997; SOUTY-GROSSET, GRANDJEAN and GOUIN, 2003) and a similar trend for this species can also be observed in the northern Italian province of South Tyrol (Autonomous Province of Bozen/Bolzano). According to historical records the autochthonous species A. pallipes was once widely distributed in several areas of the region. About 50 different localities with crayfish occurrences are known from the literature, which were mainly located in the broader main valleys and on higher plateaus (FÜREDER and MACHINO, 1999). Today, white-clawed crayfish have been extirpated from the majority of these water bodies and the ongoing trend of dramatic population decline has been well documented in a series of recent studies (FÜREDER and MACHINO, 1998, 1999; FÜREDER, OBERKOFLER and MACHINO, 2002, FÜREDER et al., 2003). The main causes of the loss of crayfish populations in South Tyrol are destruction and alteration of habitats, water pollution, and the stocking with alien crayfish and predatory fish species (FÜREDER et al., 2002).

Quite recently, an action plan was elaborated in order to preserve the white-clawed crayfish from complete extinction in South Tyrol (FÜREDER et al., 2002, 2003). The most important measures include the enhancement of environmental conditions of existing crayfish populations by wastewater treatment and the reduction of pesticides and fertilisers, and the protection and improvement of habitat structure. In addition, renaturation of suitable historical habitats as well as breeding and reintroduction programs were suggested (FÜREDER et al., 2002) and are currently implemented.

In order to define efficient conservation strategies, accurate data on systematics and population structure are crucial (SOUTY-GROSSET et al., 1997, SOUTY-GROSSET, 
GRANDJEAN and GOUIN, 2003). Although A. pallipes populations were shown to display great degrees of morphological and genetic diversity in the Alpine region (LARGIADĖR et al., 2000; LÖRTSCHER et al., 1997; SANTUCCl et al., 1997), nothing is known about the phylogenetic status and genetic composition of crayfish populations in South Tyrol. Therefore we addressed these important questions and investigated six A. pallipes populations from South Tyrol (Italy) and one population from Tyrol (Austria) by analysing variation in mitochondrial DNA gene sequences and highly variable microsatellite markers.

\section{MATERIALS AND METHODS}

\section{Molecular techniques}

Specimens of $A$. pallipes were sampled from six sites in South Tyrol (northern Italy) and one site in Tyrol (western Austria) during summer in 2002 and 2003 (Figure 1 and Table 1). Collecting was performed either by hand during the night or with crayfish traps. A non-destructive sampling procedure was employed by taking the third pereiopod from each individual. The legs were preserved separately in absolute ethanol and the animals released at the sampling locality.

Total nucleic acid was isolated from muscle tissue according to the procedure of SAMBROOK, FRITSCH and MANIATIS, (1989). A preliminary study was carried out to evaluate the suitability of mitochondrial DNA (mtDNA) sequences for the investigation of $A$. pallipes populations on a small geographical scale (Table 1). A segment of the mtDNA 16S rRNA gene (16S) was amplified with primers 1472 and 1471 (CRANDALL and FITZPATRICK, 1996). Primer combination ORCOIF (TAYLOR and HARDMAN, 2002) and H7188 (WILLIAMS et al., 2001) was used in a first step to amplify and sequence a segment of the mtDNA cytochrome $c$ oxidase subunit I (COI). The sequences from nine $A$. pallipes specimens from three populations were then aligned to design the new primer Ap-COI-

\section{Table I}

Sampling sites and number of individuals analysed for each population of A. pallipes.

\section{Tableau I}

Sites d'échantillonnage et nombre d'individus analysés dans chaque population d'A. pallipes.

\begin{tabular}{|c|c|c|c|c|c|}
\hline \multirow{3}{*}{ No } & \multirow{3}{*}{ Sampling site } & \multirow{3}{*}{$\begin{array}{l}\text { Site } \\
\text { code }\end{array}$} & \multicolumn{3}{|c|}{ No of analysed specimens } \\
\hline & & & \multicolumn{2}{|c|}{ Sequences } & \multirow{2}{*}{$\begin{array}{c}\text { Microsatellites } \\
4 \text { loci }\end{array}$} \\
\hline & & & $16 S$ & CO I & \\
\hline 1 & Angelbach ${ }^{a}$ & ANG & 7 & 8 & 39 \\
\hline 2 & Ritscherbach $^{a}$ & RIT & 10 & 10 & 40 \\
\hline 3 & Krebusbach $^{a}$ & KRB & 10 & 10 & 31 \\
\hline 4 & Hyppolithbach a & HYP & 6 & 10 & 39 \\
\hline 5 & Krebsbach Lana ${ }^{a}$ & $\mathrm{KBL}$ & 1 & 1 & 6 \\
\hline 6 & 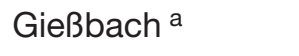 & GIB & 1 & 1 & 9 \\
\hline \multirow[t]{2}{*}{7} & Plansee ${ }^{\mathrm{b}}$ & PLS & 3 & 3 & 35 \\
\hline & & Total & 38 & 43 & 199 \\
\hline
\end{tabular}

a South Tyrol (Italy).

b Tyrol (Austria). 


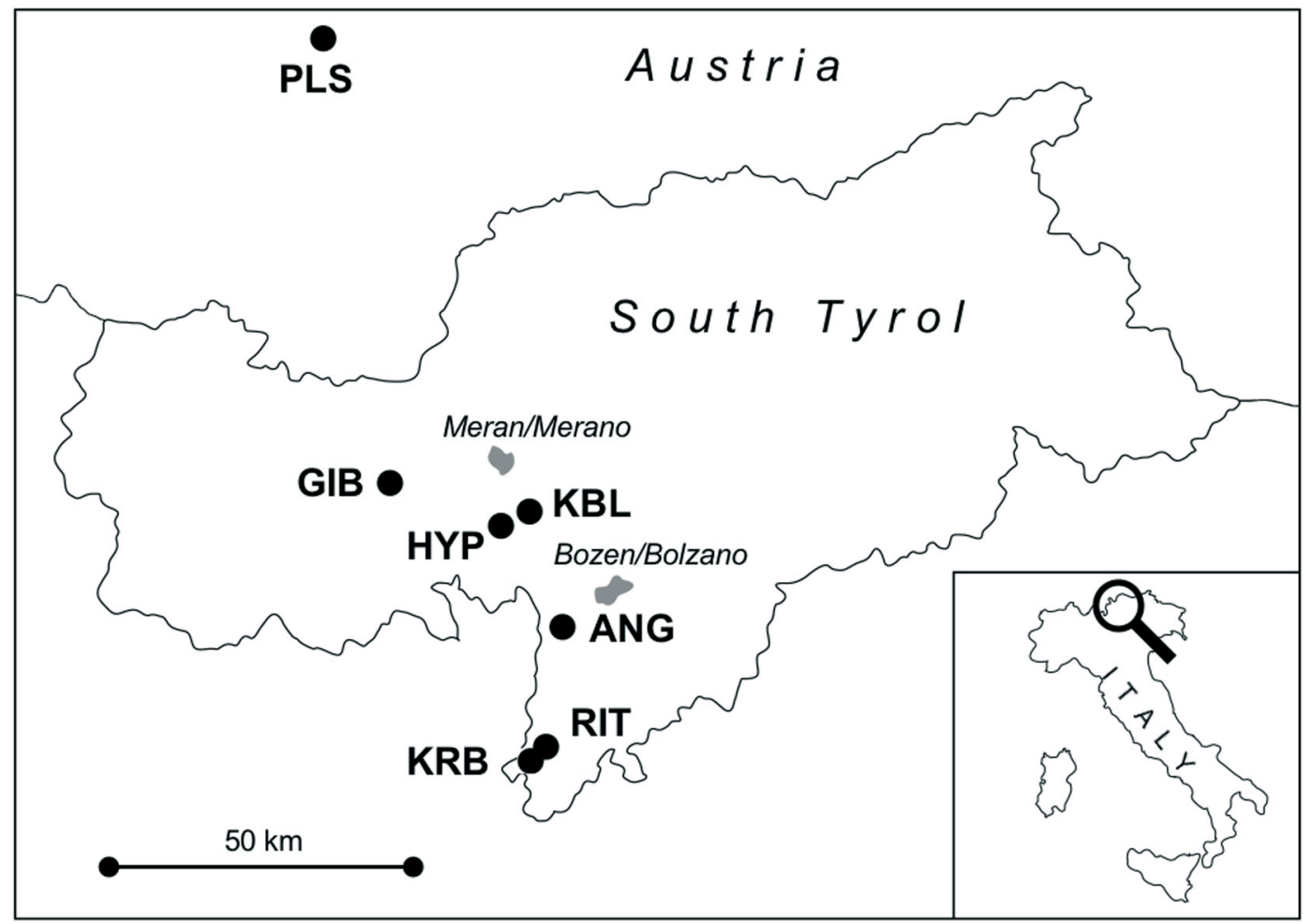

Figure 1

Sampling sites in South Tyrol (Italy) and Tyrol (Austria).

Figure 1

Sites d'échantillonnage dans le Tyrol du Sud (Italie) et dans le Tyrol (Autriche).

LB-R (Table 2). For all subsequent amplification reactions of COI primer pair ORCOIF and Ap-COI-LB-R was used.

Ten microliter reaction volumes contained $1 \mu \mathrm{M}$ of each primer, $200 \mu \mathrm{M}$ dNTP-Mix (GeneCraft, Germany), $1.5 \mathrm{mM} \mathrm{MgCl}_{2}, 0.5 \mathrm{U}$ BioTherm DNA polymerase (GeneCraft) and $2 \mu \mathrm{l}$ DNA template. Amplification reactions were run on the Mastercycler Gradient (Eppendorf, Germany) or GeneAmp PCR System 2700 (Applied Biosystems, USA) under the following conditions: 2 min initial denaturation at $94^{\circ} \mathrm{C}$ followed by 40 cycles of $94^{\circ} \mathrm{C}$ for $30 \mathrm{~s}, 48^{\circ} \mathrm{C}$ for $30 \mathrm{~s}$ and $72^{\circ} \mathrm{C}$ for $1 \mathrm{~min}$, and a final extension step at $72^{\circ} \mathrm{C}$ for $5 \mathrm{~min}$. After separation and visualization on a 1.5\% ethidium bromide stained agarose gel amplification products were purified using Montage PCR Centrifugal Filter Devices (Millipore, USA) and quantified with a spectrophotometer (BioPhotometer, Eppendorf) at 260/280 nm.

Cycle sequencing was carried out in $10 \mu \mathrm{l}$ reaction volumes with the CEQ DTCS Quick Start Kit (Beckman Coulter, USA) and the recommended amount of purified PCR product. In addition to the two amplification primers, an internal sequencing primer COIF was used (Table 2). The cycling conditions were set to 30 cycles of $20 \mathrm{~s}$ at $96^{\circ} \mathrm{C}, 20 \mathrm{~s}$ at $50^{\circ} \mathrm{C}$ and $4 \mathrm{~min}$ at $60^{\circ} \mathrm{C}$. Sequencing products were separated and detected on the CEQ 8000 Genetic Analysis System (Beckman Coulter).

Four microsatellite loci, Ap1, Ap2, Ap3 and Ap6 (GOUIN, GRANDJEAN and SOUTYGROSSET, 2000), were employed to additionally assess the genetic structure of $A$. pallipes populations. Each forward primer was fluorescently labelled with a Beckman WellRED dye (Beckman Coulter; Table 2). Ten microliter amplification reaction volumes contained $200 \mathrm{nM}$ 


\section{Table II}

Primers used to analyse mtDNA and microsatellite loci in A. pallipes populations.

Tableau II

Amorces utilisées pour l'analyse de l'ADN mitochondrial et des loci microsatellites dans les populations d'A. pallipes.

\begin{tabular}{|c|c|c|c|}
\hline & Primer name & Primer sequence (5'-3') & Reference \\
\hline \multicolumn{4}{|l|}{ mt DNA } \\
\hline \multirow[t]{2}{*}{$16 S$} & 1471 & СCTGTTA(AGCT)CAAAAACAT & $\begin{array}{l}\text { CRANDALL and } \\
\text { FITZPATRICK, } 1996\end{array}$ \\
\hline & 1472 & AGATAGAAACCAACCTGG & $\begin{array}{l}\text { CRANDALL and } \\
\text { FITZPATRICK, } 1996\end{array}$ \\
\hline \multirow[t]{4}{*}{$\mathrm{COI}$} & COIF & CCAGCTGGAGGAGGAGA(CT)CC & $\begin{array}{l}\text { WILLIAMS et al., } \\
2001\end{array}$ \\
\hline & $\mathrm{H} 7188$ & CATTTAGGCCTAAGAAGTGTTG & $\begin{array}{l}\text { WILLIAMS et al., } \\
2001\end{array}$ \\
\hline & ORCOIF & AACGCAACGATGATTITTTTCTAC & $\begin{array}{l}\text { TAYLOR and } \\
\text { HARDMAN, } 2002\end{array}$ \\
\hline & Ap-COI-LB-R & AAACAAAGGAAATCCATGAAC & $\begin{array}{l}\text { designed for this } \\
\text { study }\end{array}$ \\
\hline \multicolumn{4}{|c|}{ Microsatellite locus } \\
\hline \multirow[t]{2}{*}{ Ap1 } & Ap1-F & D2 - TCTTGGGGATTGGCTAGTTG & GOUIN et al., 2000 \\
\hline & Ap1-R & CCTGAACTAAAAGGTGCTTTGG & $\div$ \\
\hline \multirow[t]{2}{*}{ Ap2 } & Ap2-F & D3 - TTCGATATAACCGTTTGACCTG & $\div$ \\
\hline & Ap2-R & TCAGACTTTGGCCATTGAAG & $\div$ \\
\hline \multirow[t]{2}{*}{ Ap3 } & Ap3-F & D4 - CGCCTATCTAACCTTGGTTGTC & $\div$ \\
\hline & Ap3-R & GGACTTGGGAAGCCTTGTG & $\div$ \\
\hline \multirow[t]{2}{*}{ Ap6 } & Ap6-F & D3 - GCTGTGTGGGATGGAGGT & $\div$ \\
\hline & Ap6-R & CACTAGCGTATTCAAGCAACT & $\div$ \\
\hline
\end{tabular}

D2, D3, D4... Beckman WellRED fluorescent dyes.

(Ap1/Ap3 multiplex reaction) or $400 \mathrm{nM}$ (Ap2 and Ap6) of each primer, $200 \mu \mathrm{M}$ dNTP-Mix (GeneCraft), $1.5 \mathrm{mM} \mathrm{MgCl}_{2}, 0.5 \mathrm{U}$ HotMaster Taq DNA polymerase (Eppendorf) and $2 \mu \mathrm{l}$ of DNA template. The thermocycler was programmed to perform an initial denaturation step of $2 \mathrm{~min}$ at $94^{\circ} \mathrm{C}$ followed by 30 to 35 cycles of $30 \mathrm{~s}$ at $94^{\circ} \mathrm{C}, 30 \mathrm{~s}$ at $60^{\circ} \mathrm{C}$ (Ap1/Ap3 and Ap6) or $54^{\circ} \mathrm{C}(\mathrm{Ap} 2)$ and $45 \mathrm{~s}$ at $65^{\circ} \mathrm{C}$, and a final extension of $10 \mathrm{~min}$ at $65^{\circ} \mathrm{C}$.

Each sample was run with an internal size standard on the CEQ 8000 Genetic Analysis System (Beckman Coulter). Sizing of fragments and assignment to particular size classes was performed by using the Fragment Analysis Software of the same manufacturer. To control the validity of the sizing and verify the assignment to size classes, all alleles allocated to a particular class were re-examined by eye.

\section{Data analyses}

Partial sequences of each of the two mtDNA genes were aligned by eye using the computer program SEQUENCHER Version 4.2 for Windows (Gene Codes Corporation, 
Ann Arbor, USA) and unique haplotypes were identified. The 16S-dataset was expanded with additional sequences of $A$. pallipes from GenBank (accession numbers AF237590AF237610 and AJ242700-AJ242711), which covered the whole distribution range of the species. PAUP* version 4.0 Beta (SWOFFORD, 2002) was used to calculate pairwise distances among sequences. Gaps were treated as missing data.

Genetic variability of the four microsatellite loci was estimated for each population in terms of the number of alleles $\left(\mathrm{N}_{\mathrm{A}}\right)$, the number of genotypes $\left(\mathrm{N}_{\mathrm{G}}\right)$, allele frequencies, and the observed $\left(\mathrm{H}_{\mathrm{O}}\right)$ and expected heterozygosity $\left(\mathrm{H}_{\mathrm{E}}\right)$. Departure from Hardy-Weinberg equilibrium was tested according to the procedure of GUO and THOMPSON (1992) using a Markov chain Monte Carlo series of permutations, as implemented in ARLEQUIN version 2.0 (SCHNEIDER et al., 2000). Genotypic linkage disequilibrium was tested for all pairs of polymorphic loci in each population as well as across populations with the software GENEPOP version 3.3 (RAYMOND and ROUSSET, 1995), which performs Fisher's exact test by using a Markov chain (GUO and THOMPSON, 1992).

Exact probability tests for genotypic and genic differentiation among all pairs of populations were conducted by using GENEPOP version 3.3 (RAYMOND and ROUSSET, 1995). The computer software ARLEQUIN version 2.0 (SCHNEIDER et al., 2000) was used to calculate pairwise $F_{S T}$ values among all population pairs, as an additional measure of population subdivision (SLATKIN, 1995). All significance values resulting from multiple comparisons were corrected for type I errors by applying the sequential Bonferroni procedure (RICE, 1989).

\section{RESULTS}

The alignment of the $16 \mathrm{~S}$ sequences comprised 430 nucleotide positions. No base pair substitutions were observed among the sequences of all 38 specimens of $A$. pallipes (Table 1). The only variability was detected in a poly-adenine region where all individuals from the RIT population had a single nucleotide insert (A) and two individuals from the ANG population had a 3-bp insert (AAA). The most common 16S haplotype (lacking inserts) was identical to haplotype S3, which was deposited in GenBank under the accession number AJ242706 and was found to be distributed in diverse populations of $A$. pallipes in Austria, Switzerland and north-western Italy (LARGIADÈR et al., 2000). Sequences of the $\mathrm{COI}$ gene segment were obtained from 43 individuals and the length of the alignment was 1,063 nucleotides. In general, one single haplotype was found to be distributed within and among all populations surveyed. An exception was population KRB, where a second haplotype was found in two individuals, which differed by a single point mutation.

Only population KRB was polymorphic at all the four investigated microsatellite loci, while populations ANG, RIT and HYP were polymorphic at three loci, Ap2, Ap3 and Ap6 (Table 3). Populations KBL, GIB and PLS were fixed for a single allele at loci Ap1, Ap3 and Ap6, while for locus Ap2 between 2 and 4 alleles were found. The overall number of alleles across all loci ranged from 2 to 10 . The highest number of private alleles was found in population KRB. Allele frequencies for each locus and population are shown in Figure 2. The average observed heterozygosity across all loci and populations amounted to 0.525 ( \pm 0.1995). Three populations displayed significant deviations from expected

\section{Figure 2}

Allele frequency distributions across microsatellite loci and populations. Asterisks denote private alleles.

\section{Figure 2}

Distributions des fréquences d'allèles sur les loci microsatellites et dans les populations. Les astérisques signalent les allèles privées. 
MICROSATELLITE LOCUS
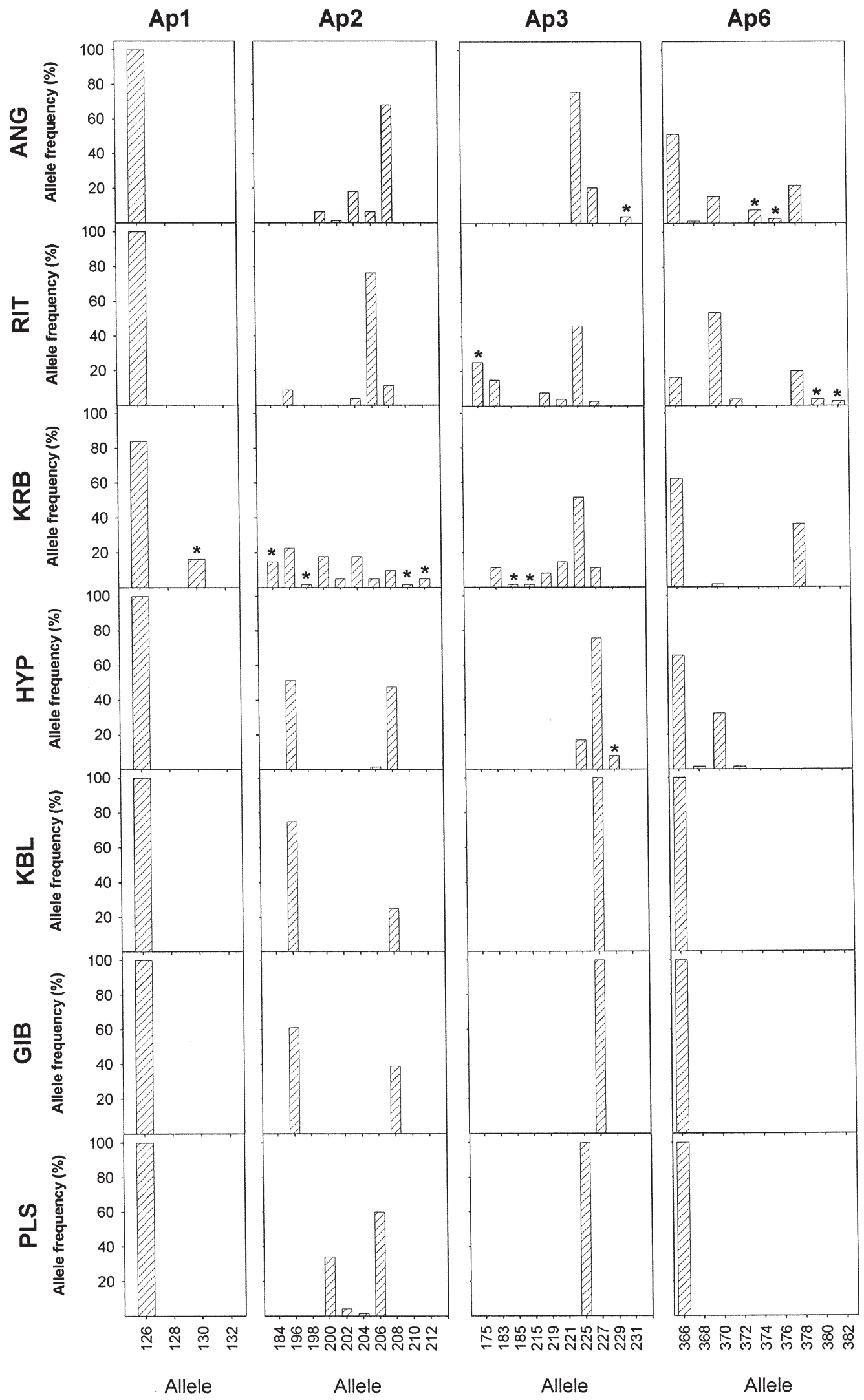
Hardy-Weinberg proportions after a sequential Bonferroni correction: KRB at loci Ap3 and Ap6, and HYP at locus Ap6 at the 5\% significance level, and ANG at locus Ap6 at the $1 \%$ significance level (Table 3). Only population RIT was found to be in Hardy-Weinberg equilibrium at all four loci. Genotypic linkage disequilibrium was tested to verify that there was no association among genotypes at different loci. Tests could be performed for populations ANG, RIT and HYP for the polymorphic loci Ap2, Ap3 and Ap6, and for population KRB for all pairs of loci. The estimated P-values ranged from 0.094 to

Table III

Summary table of variation detected at four microsatellite loci in seven $A$. pallipes populations. The numbers of alleles $\left(\mathrm{N}_{\mathrm{A}}\right)$, number of genotypes $\left(\mathrm{N}_{\mathrm{G}}\right)$, observed $\left(H_{O}\right)$ and expected $\left(H_{E}\right)$ heterozygosity are given. Number of specimens analysed for each population is indicated in parentheses. Asterisks indicate significant deviation from Hardy-Weinberg equilibrium at the $5 \%$ level $\left({ }^{*}\right)$ and $1 \%$ level $\left({ }^{* *}\right)$ after table-wide Bonferroni correction.

Table III

Tableau résumé des variations détectées sur quatre loci microsatellites dans sept populations d'A. pallipes. Les nombres d'allèles $\left(N_{A}\right)$, le nombre de génotypes $\left(N_{G}\right)$, l'hétérozygotie observée $\left(H_{O}\right)$ et attendue $\left(H_{E}\right)$ sont indiqués. Le nombre de spécimens analysés dans chaque population est indiqué entre parenthèses. Les astérisques indiquent une déviation significative de l'équilibre de Hardy-Weinberg de $5 \%\left(^{*}\right)$ et de $1 \%\left(^{* *}\right)$, après correction selon la table de Bonferroni.

\begin{tabular}{|c|c|c|c|c|c|c|c|c|c|c|}
\hline Locus & & $\begin{array}{l}\text { ANG } \\
\text { (39) }\end{array}$ & $\begin{array}{l}\text { RIT } \\
(40)\end{array}$ & $\begin{array}{c}\text { KRB } \\
\text { (31) } \\
\end{array}$ & $\begin{array}{l}\text { HYP } \\
\text { (39) } \\
\end{array}$ & $\begin{array}{c}\text { KBL } \\
\text { (6) }\end{array}$ & $\begin{array}{l}\text { GIB } \\
(9)\end{array}$ & $\begin{array}{l}\text { PLS } \\
(35)\end{array}$ & $\begin{array}{c}\text { Mean } \\
\mathrm{N}_{\mathrm{A}}\end{array}$ & $\begin{array}{c}\text { Total } \\
\mathbf{N}_{\mathbf{A}}\end{array}$ \\
\hline \multirow[t]{4}{*}{ Ap1 } & $\mathrm{N}_{\mathrm{A}}$ & 1 & 1 & 2 & 1 & 1 & 1 & 1 & 1.14 & 2 \\
\hline & $\mathrm{N}_{\mathrm{G}}$ & 1 & 1 & 3 & 1 & 1 & 1 & 1 & & \\
\hline & $\mathrm{H}_{\mathrm{O}}$ & - & - & 0.258 & - & - & - & - & & \\
\hline & $\mathrm{H}_{\mathrm{E}}$ & - & - & 0.302 & - & - & - & - & & \\
\hline \multirow[t]{4}{*}{ Ap2 } & $\mathrm{N}_{\mathrm{A}}$ & 5 & 4 & 10 & 3 & 2 & 2 & 4 & 4.29 & 10 \\
\hline & $\mathrm{N}_{\mathrm{G}}$ & 7 & 5 & 19 & 4 & 2 & 2 & 5 & & \\
\hline & $\mathrm{H}_{\mathrm{O}}$ & 0.564 & 0.400 & 0.710 & 0.487 & 0.500 & 0.111 & 0.514 & & \\
\hline & $\mathrm{H}_{\mathrm{E}}$ & 0.537 & 0.4392 & 0.8630 & 0.519 & 0.409 & 0.765 & 0.677 & & \\
\hline \multirow[t]{4}{*}{ Ap3 } & $\mathrm{N}_{\mathrm{A}}$ & 3 & 6 & 7 & 3 & 1 & 1 & 1 & 3.14 & 10 \\
\hline & $\mathrm{N}_{\mathrm{G}}$ & 4 & 10 & 11 & 5 & 1 & 1 & 1 & & \\
\hline & $\mathrm{H}_{\mathrm{O}}$ & 0.308 & 0.750 & $0.548^{\star}$ & 0.359 & - & - & - & & \\
\hline & $\mathrm{H}_{\mathrm{E}}$ & 0.389 & 0.731 & 0.710 & 0.535 & - & - & - & & \\
\hline \multirow[t]{4}{*}{ Ap6 } & $\mathrm{N}_{\mathrm{A}}$ & 6 & 6 & 3 & 4 & 1 & 1 & 1 & 3.14 & 9 \\
\hline & $\mathrm{N}_{\mathrm{G}}$ & 7 & 9 & 3 & 4 & 1 & 1 & 1 & & \\
\hline & $\mathrm{H}_{\mathrm{O}}$ & $0.819^{\star \star}$ & 0.650 & $0.759^{\star}$ & $0.667^{\star}$ & - & - & - & & \\
\hline & $\mathrm{H}_{\mathrm{E}}$ & 0.667 & 0.675 & 0.492 & 0.476 & - & - & - & & \\
\hline \multicolumn{2}{|c|}{ Mean $\mathrm{N}_{\mathrm{A}} /$ pop } & 3.75 & 4.25 & 5.50 & 2.75 & 1.25 & 1.25 & 1.75 & & \\
\hline \multicolumn{2}{|c|}{ Mean $\mathrm{H}_{\mathrm{o}}$} & 0.56 & 0.60 & 0.57 & 0.50 & & & & & \\
\hline \multicolumn{2}{|c|}{ Mean $\mathrm{H}_{\mathrm{E}}$} & 0.53 & 0.62 & 0.59 & 0.51 & & & & & \\
\hline
\end{tabular}

- Test could not be performed because locus is monomorphic. 
0.857 , and thus the null hypothesis of independence among genotypes across all four microsatellite loci was accepted.

The exact tests across all loci and populations revealed significant differences in both allele and genotype frequency between 19 population pairs. For population pair KBL and HYP significant genotypic differentiation was found, while allelic differentiation was not significant. Population pair GIB and KBL showed neither significant genotypic nor allelic differentiation (Table 4). Pairwise $F_{S T}$ values were significantly different from zero in 20 out of 21 pairwise comparisons. Congruent with the results of the exact tests for genotypic and genic differentiation, no significant difference was found between populations GIB and $\mathrm{KBL}$ (Table 4). Pairwise $\mathrm{F}_{\mathrm{ST}}$ estimates ranged from zero to 0.749 with a mean value of $0.342( \pm 0.1977)$.

\section{Table IV}

Population pairwise $F_{\mathrm{ST}}$ estimates obtained from microsatellite data (below diagonal) and levels of significance for the exact test for population differentiation (genotypic/genic differentiation; above diagonal) after sequential Bonferroni correction.

Tableau IV

Estimations des $\mathrm{F}_{\mathrm{ST}}$ par paires de populations obtenues à partir des données des microsatellites (en dessous de la diagonale) et niveau de significativité pour le test exact de différentiation des populations (différentiation génotypisue/génique; au-dessus de la diagonale) après correction selon la séquence de Bonferroni.

\begin{tabular}{|c|c|c|c|c|c|c|c|}
\hline & ANG & RIT & KRB & HYP & KBL & GIB & PLS \\
\hline ANG & & $* * * / * * *$ & $\star * * / * \star$ & $* * * / * * *$ & $* * * / * \star *$ & $* * * / * * *$ & $* \star * / * * *$ \\
\hline RIT & $0.2733^{\star \star \star}$ & & 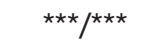 & 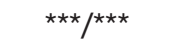 & 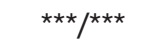 & 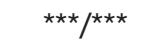 & 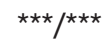 \\
\hline KRB & $0.1279^{\star \star \star}$ & $0.2263^{\star \star \star *}$ & & 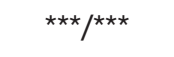 & 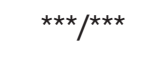 & $\star \star \star * / * \star \star *$ & $\star \star \star * / * \star * *$ \\
\hline HYP & $0.2655^{\star \star \star}$ & $0.3745^{\star \star \star}$ & $0.2378^{\star \star *}$ & & */NS & $\star * / *$ & 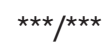 \\
\hline KBL & $0.4330^{\star \star \star}$ & $0.5000^{* \star *}$ & $0.2916^{\star * *}$ & $0.1058^{*}$ & & NS/NS & $\star \star * \star / * \star *$ \\
\hline GIB & $0.4126^{\star \star \star}$ & $0.5045^{\star \star \star}$ & $0.2974^{\star \star \star}$ & $0.0917^{\star}$ & -0.0289 & & 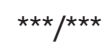 \\
\hline PLS & $0.3596^{\star \star \star}$ & $0.3960^{\star * *}$ & $0.2773^{\star \star *}$ & $0.5515^{\star \star *}$ & $0.7491^{\star \star \star}$ & $0.7394^{\star \star \star}$ & \\
\hline
\end{tabular}

* $\mathrm{P}<0.05 ;{ }^{* \star} \mathrm{P}<0.01 ;{ }^{* \star *} \mathrm{P}<0.001 ; \mathrm{NS} . .$. not significant.

\section{DISCUSSION}

Analyses of mtDNA sequences and microsatellite DNA variation in A. pallipes from South Tyrol did not yield the same results. While almost complete monomorphism was found for $16 \mathrm{~S}$ and $\mathrm{COI}$ sequences, microsatellite patterns revealed genetic diversity within and across the four populations ANG, RIT, KRB and HYP. Such a finding is not surprising considering the differences in the modes of inheritance and mutation rates of mitochondrial and nuclear DNA. So far, several authors studied population structure and phylogeographic distribution patterns of the white-clawed crayfish on a larger geographical scale by employing RFLP analyses of the mtDNA or by sequencing the 16S rRNA gene (GRANDJEAN et al., 2000, 2001, GRANDJEAN, BOUCHON and SOUTY-GROSSET, 2002; GRANDJEAN and SOUTY-GROSSET, 2000; LARGIADÈR et al., 2000). Pronounced population structure was found among different localities in Italy, France and Switzerland, whereas no genetic variation was observed across Spanish populations and among the most northern French and English populations. However, intrapopulation variability was 
found to be very low or completely absent. An exception was found for populations in the southern part of France, where mitochondrial and microsatellite markers revealed high levels of within-population variability (SOUTY-GROSSET, GRANDJEAN and GOUIN, 2003).

In general, the distribution patterns of genetic diversity in $A$. pallipes and many other species can be explained by Pleistocene palaeogeographic events (BERNATCHEZ and WILSON, 1998; GRANDJEAN and SOUTY-GROSSET, 2000; HEWITT, 1996; LARGIADÈR et al., 2000). During the ice ages many species were confined to southern refugial zones located on the Balkan, Apennine and Iberian peninsulas (TABERLET et al., 1998). It is believed that after glaciation the white-clawed crayfish recolonised new territories from multiple refugial areas (reviewed in HOLDICH, 2002). The incidence of the same mtDNA $16 S$ haplotype in South Tyrol, and at different localities in Switzerland and north-western Italy could be a consequence of a rapid postglacial recolonisation event from the same refugial population about 15,000-10,000 years ago. The alternative hypothesis of human translocation, which appeared to be a rather common activity in Europe (see MACHINO et al.,2004), seems less probable for the South Tyrolean populations, for which microsatellite DNA data displayed certain degrees of genetic variability. Moreover, microsatellite markers revealed significant population differentiation on a small geographical scale. This pattern is either caused by an effective separation of populations and absence of gene flow soon after postglacial colonization of the different brooks, or alternatively by a recent isolation of populations due to the fragmentation of habitats. In the latter case, population differentiation would arise from the stochastic process of genetic drift enhanced by decreases in effective population size.

South Tyrol experienced major landscape changes during the last two centuries (FEUERSTEIN, 1999). River regulation, damming, and the draining of swamps and wetlands were important measures of land reclamation, which provided the fundament for the development of agriculture, but also led to great losses and fragmentation of aquatic habitats (FÜREDER et al., 2003). As a consequence thereof, the few existing crayfish populations in South Tyrol are limited to small isolated stretches of little creeks (FÜREDER, OBERKOFLER and MACHINO, 2002; FÜREDER and MACHINO, 1999). Although the present-day isolation of crayfish populations is an obvious fact, which could be responsible for the formation of the observed patterns of genetic structure, we cannot exclude the possibility that these populations represented genetically differentiated stocks before the initiation of human activities. GOUIN et al. (2002) found extensive gene flow for $A$. pallipes within a single brook, showing that this crayfish species is able to spread over remarkable distances of favourable habitat in the absence of a barrier. In contrast, surveys of different streams within the same basin, which were characterized by a limited degree of habitat fragmentation, displayed high degrees of population structure as well as isolation by distance (SOUTY-GROSSET, GRANDJEAN and GOUIN, 2003). Such findings clearly demonstrate the low dispersal ability of the species over longer distances. The assumption of long-term historical population separation in South Tyrol could also be supported by the finding of haplotype variants, which differed only by deletions or insertions in a poly-adenine stretch of the $16 \mathrm{~S}$ sequence. Given the fact that mutation rates of mtDNA are higher than those of nuclear DNA, and that mononucleotide repeats have an at least ten-fold increased susceptibility to insertion and deletion mutations compared to non-repetitive sequences (DIERINGER and SCHLÖTTERER, 2003), it is probable that these mutations emerged after colonisation of the present habitats. Mitochondrial DNA has a haploid genome and is usually only maternally inherited. The effective population size for mtDNA is approximately $1 / 4$ of that for nuclear DNA genes so that genetic drift is more pronounced and fixation rates are faster. Regarding the RIT population, where all the surveyed individuals displayed a $16 S$ haplotype variant with a single adenosine insert, one could speculate that this haplotype arose by mutation quite recently and was fixed by lineage sorting in the absence of gene flow. Another recent slippage-like mutation event 
and a transition base pair substitution could be assumed for the other haplotype variants, with the difference that the original haplotype was not lost via drift, but coexists with the new haplotype.

The genetic diversity in the populations ANG, RIT, KRB and HYP was higher than that found in the largest $A$. pallipes population in the Poitou-Charentes region in France, which was determined with the same microsatellite markers (GOUIN, GRANDJEAN and SOUTY-GROSSET, 2000, GOUIN et al., 2002). While for the French population a mean heterozygosity value of 0.38 was found, the average observed heterozygosity across all loci and populations in South Tyrol amounted to 0.53 . The ratio of the total number of alleles for French and South Tyrolean populations was 2:10, 4:10 and 2:9 for loci Ap2, Ap3 and Ap6, respectively. This would imply that the effective population sizes in South Tyrol have not yet been considerably affected by the fragmentation of habitats.

Contrary to the previous populations, almost complete absence of genetic diversity was found in populations KBL and GIB. Although such a result could emerge from the small number of individuals being analysed from these populations we believe that this finding reflects a recent bottleneck. Only a small number of specimens could be caught from these populations during sampling trials in summer 2003. However, during field studies in the year 2001 no single crayfish was observed at these localities (FÜREDER et al., 2003). Since the patterns of analysed microsatellite loci are exactly the same for all individuals in both populations, we presume that these two brooks were re-stocked quite recently with hatchery reared specimens originating from the same genetic pool, most probably from the HYP population or from another population, which had gone extinct.

The only Austrian population included in this study also lacked genetic variability. Such a result was not surprising, since for the PLS population we expected to see the results of a founder effect. FÜREDER and MACHINO (1995) reported the story given by elder residents about the human introduction of white-clawed crayfish to the lake at the beginning of the $20^{\text {th }}$ century. It seems that these crayfish do not suffer from inbreeding depression as a very large and dense population has developed. Based on mtDNA we can definitely reject the possibility of a French or Carinthian origin of $A$. pallipes in PLS (BARIC et al., 2005). An Italian origin seems very likely, but it is not possible to localise its exact provenience.

In the present study we showed that analyses of population structure and genetic variability on a small geographical scale largely benefit from the use of a combination of different molecular markers. Significant structure among some of the surveyed populations could only be observed after analyzing microsatellite DNA. Nevertheless, mtDNA proved to be a valuable tool in resolving the systematic position of $A$. pallipes from South Tyrol (see BARIC et al., 2005).

Based on our results, we can make management recommendations for the remaining crayfish populations. As we cannot exclude the possibility of long-term genetic isolation of populations, we propose to treat each of the four populations ANG, RIT, KRB and HYP as unique gene pools that warrant individual recognition for conservation and management. All possible measures should be taken to protect, improve and enlarge their habitats in order to prevent a decrease of effective population size and loss of genetic variability. Additionally, brook-specific supportive breeding would contribute to maintain genetic diversity and integrity of populations. If possible, connections among streams should be established to promote gene flow among populations. However, mixing of populations by translocation in order to increase genetic variability should be avoided, since populations could be adapted to local environmental conditions and out breeding could have adverse effects. 


\section{ACKNOWLEDGEMENTS}

The present work is part of the project "CRAYFISH-GENEFLOW" that was funded by the European Union under its Interrreg IIIA programme between Italy and Austria, and the Governments of South Tyrol (Italy) and Tyrol (Austria). We thank Christine Kerschbamer for technical assistance, and Daniela Sint, Josef Leiter, Andreas Declara, Bettina Sonntag, Michaela Salcher and Sebastian Voigt for field work. We are grateful to two anonymous reviewers for comments that helped to improve the manuscript.

\section{REFERENCES}

BARIC S., HÖLLRIGL A., KERSCHBAMMER C., FÜREDER L., PETUTSCHNIG J., DALLA VIA J., 2005. Update of the molecular phylogeny of the Austropotamobius pallipes species complex by including specimens from South Tyrol (Italy) and Carinthia (Austria). In: FÜREDER L. and SOUTY-GROSSET C., 2005: European native crayfish in relation to land-use and habitat deterioration with a special focus on Austropotamobius torrentium, CRAYNET, Volume 3, Bull. Fr. Pêche Piscic., 376377, 627-636.

BERNARDO J.M., ILHEU M., COSTA A.M., 1997. Distribution, population structure and conservation of Austropotamobius pallipes in Portugal. Bull. Fr. Pêche Piscic., 347, 617-624.

BERNATCHEZ L., WILSON C.C., 1998. Comparative phylogeography of Neartic and Paleartic fishes. Molecular Ecology, 7, 431-452.

CRANDALL K.A., FITZPATRICK J.F., 1996. Crayfish molecular systematics: using a combination of procedures to estimate phylogeny. Systematic Biology, 45, 1-26.

DIERINGER D., SCHLÖTTERER C., 2003. Two distinct modes of microsatellite mutation processes: evidence from the complete genomic sequences of nine species. Genome Research, 13, 2242-2251.

DYNESIUS M., NILSSON C., 1994. Fragmentation and flow regulation of river systems in the northern third of the world. Science, 266, 753-762.

FEUERSTEIN G., 1999. Grundzüge der Landwirtschaft Südtirols. Der Schlern, 73, 778-784.

FÜREDER L., MACHINO Y., 1995. Record of the white-clawed crayfish Austropotamobius pallipes (Lereboullet, 1858) from Plansee (Tyrol, Austria). Berichte des Naturwissenschaftlich-Medizinischen Vereins in Innsbruck, 82, 241-246.

FÜREDER L., MACHINO Y., 1998. Historische und rezente Flusskrebsvorkommen in Tirol, Südtirol und Vorarlberg. Stapfia, 58 (137), 77-88.

FÜREDER L., MACHINO Y., 1999. Past and present crayfish situations in Tyrol (Austria and Northern Italy). Freshwater Crayfish, 12, 751-764.

FÜREDER L., OBERKOFLER B., HANEL R., LEITER J., THALER B., 2003. The freshwater crayfish Austropotamobius pallipes in South Tyrol: heritage species and bioindicator. In: REYNOLDS J. and SOUTY-GROSSET C., 2003: The endangered native crayfish Austropotamobius pallipes, Bioindicator and heritage species, CRAYNET, volume 1, Bull. Fr. Pêche Piscic., 370-371, 79-95.

FÜREDER L., OBERKOFLER B., HANEL R., MACHINO Y., 2002. Freshwater crayfish in South Tyrol (Italy): distribution and protection measures of endangered Austropotamobius pallipes. Bull. Fr. Pêche Piscic., 367, 651-662.

FÜREDER L., OBERKOFLER B., MACHINO Y., 2002. Flusskrebse in den Gewässern Südtirols: Verbreitung, ökologische Bedeutung und Gefährdung. Berichte des Naturwissenschaftlich-Medizinischen Vereins in Innsbruck, 89, 179-199. 
GHERARDI F., SOUTY-GROSSET C., REYNOLDS J., 2003. Understanding and managing biodiversity in relation to native crayfish populations in Europe. In: REYNOLDS J. and SOUTY-GROSSET C., 2003: The endangered native crayfish Austropotamobius pallipes, Bioindicator and heritage species, CRAYNET, volume 1, Bull. Fr. Pêche Piscic., 370-371, 7-14.

GOUIN N., GRANDJEAN F., SOUTY-GROSSET C., 2000. Characterization of microsatellite loci in the endangered freshwater crayfish Austropotamobius pallipes (Astacidae) and their potential use in other decapods. Molecular Ecology, 9, 636-638.

GOUIN N., SOUTY-GROSSET C., ROPIQUET A., GRANDJEAN F., 2002. High dispersal ability of Austropotamobius pallipes revealed by microsatellite markers in a French brook. Bull. Fr. Pêche Piscic., 367, 681-689.

GRANDJEAN F., BOUCHON D., SOUTY-GROSSET C., 2002. Systematics of the European endangered crayfish species Austropotamobius pallipes (Decapoda: Astacidae) with a re-examination of the status of Austropotamobius berndhauseri. Journal of Crustacean Biology, 22, 677-681.

GRANDJEAN F., GOUIN N., SOUTY-GROSSET C., DIÉGUEZ-URIBEONDO J., 2001. Drastic bottlenecks in the endangered crayfish species Austropotamobius pallipes in Spain and implications for its colonization history. Heredity, 86, 431-438.

GRANDJEAN F., HARRIS D.J., SOUTY-GROSSET C., CRANDALL K.A., 2000. Systematics of the European endangered crayfish species Austropotamobius pallipes (Decapoda: Astacidae). Journal of Crustacean Biology, 20, 522-529.

GRANDJEAN F., SOUTY-GROSSET C., 2000. Mitochondrial DNA variation and population genetic structure of the white-clawed crayfish, Austropotamobius pallipes pallipes. Conservation Genetics, 1, 309-319.

GUO S., THOMPSON E., 1992. Performing the exact test of Hardy-Weinberg proportion for multiple alleles. Biometrics, 48, 361-372.

HEWITT G.M., 1996. Some genetic consequences of ice ages, and their role in divergence and speciation. Biological Journal of the Linnean Society, 58, 247-276.

HOLDICH D.M., ROGERS W.D., 1997. The white-clawed crayfish, Austropotamobius pallipes, in Great Britain and Ireland with particular reference to its conservation in Great Britain. Bull. Fr. Pêche Piscic., 347, 597-616.

HOLDICH D.M., 2002. Distribution of crayfish in Europe and some adjoining countries. Bull. Fr. Pêche Piscic., 367, 611-650.

LARGIADÈR C.R., HERGER F., LÖRTSCHER M., SCHOLL A., 2000. Assessment of natural and artificial propagation of the white-clawed crayfish (Austropotamobius pallipes species complex) in the Alpine region with nuclear and mitochondrial markers. Molecular Ecology, 9, 25-27.

LÖRTSCHER M., STUCKI T.P., CLALÜNA M., SCHOLL A., 1997. Phylogeographic structure of Austropotamobius pallipes populations in Switzerland. Bull. Fr. Pêche Piscic., 347, 649-661.

MACHINO Y., FÜREDER L., LAURENT P.J., PETUTSCHNIG J., 2004. Introduction of the white-clawed crayfish Austropotamobius pallipes in Europe. Berichte des Naturwissenschaftlich-Medizinischen Vereins in Innsbruck, 91, 187-212.

NEY-NIFFLE M., MANGEL M., 2000. Habitat loss and changes in the species-area relationship. Conservation Biology, 14, 893-898.

RAYMOND M., ROUSSET F., 1995. GENEPOP (version 1.2): population genetics software for exact tests and ecumenicism. Journal of Heredity, 86, 248-249. 
RICE W.R., 1989. Analyzing tables of statistical tests. Evolution, 43, 223-225.

SAMBROOK J., FRITSCH E.F., MANIATIS T., 1989. Molecular Cloning: a Laboratory Manual. Cold Spring Harbour Laboratory Press, New York.

SANTUCCI F., IACONELLI M., ANDREANI P., CIANCHI R., NASCETTI G., BULLINI L., 1997. Allozyme diversity of European freshwater crayfish of the genus Austropotamobius. Bull. Fr. Pêche Piscic., 347, 663-676.

SCHNEIDER S., ROESSLI D., EXCOFFIER L., 2000. ARLEQUIN: A software for population genetics data analysis, Version 2.000. Genetics and Biometry Laboratory, Department of Anthropology, University of Geneva, Geneva.

SLATKIN M., 1995. A measure of population subdivision based on microsatellite allele frequencies. Genetics, 139, 457-462.

SOUTY-GROSSET C., GRANDJEAN F., GOUIN N., 2003. Involvement of genetics in knowledge, stock management and conservation of Austropotamobius pallipes in Europe. In: REYNOLDS J. and SOUTY-GROSSET C., 2003: The endangered native crayfish Austropotamobius pallipes, Bioindicator and heritage species, CRAYNET, volume 1, Bull. Fr. Pêche Piscic., 370-371, 165-179.

SOUTY-GROSSET C., GRANDJEAN F., RAIMOND R., FRELON M., DEBENEST C., BRAMARD M., 1997. Conservation genetics of the white-clawed crayfish Austropotamobius pallipes: the usefulness of the mitochondrial DNA marker. Bull. Fr. Pêche Piscic., 347, 677-692.

SWOFFORD D.L., 2002. PAUP*: Phylogenetic Analysis Using Parsimony (and Other Methods), Version 4.0 Beta. Sinauer Associates, Sunderland.

TABERLET P., FUMAGALLI L., WUST-SAUCY A., COSSON J., 1998. Comparative phylogeography and postglacial colonization routes in Europe. Molecular Ecology, 7, 453-464.

TAYLOR C.A., HARDMAN M., 2002. Phylogenetics of the crayfish subgenus Crockerinus, genus Orconectes (Decapoda: Cambaridae), based on cytochome oxidase I. Journal of Crustacean Biology, 22, 874-881.

WILLIAMS S.T., KNOWLTON N., WEIGT L.A., JARA J.A., 2001. Evidence for three major clades within the snapping shrimp genus Alpheus inferred from nuclear and mitochondrial gene sequence data. Molecular Phylogenetics and Evolution, 30, 375-389. 